Article

\title{
Sustaining Employability: A Process for Introducing Cloud Computing, Big Data, Social Networks, Mobile Programming and Cybersecurity into Academic Curricula
}

\author{
Razvan Bologa *, Ana-Ramona Lupu, Catalin Boja and Tiberiu Marian Georgescu \\ Department of Computer Science and Cybernetics, Bucharest University of Economic Studies, \\ 010374 Bucharest, Romania; ramona.bologa@ie.ase.ro (A.-R.L.); catalin.boja@ie.ase.ro (C.B.); \\ tiberiugeorgescu@ase.ro (T.M.G.) \\ * Correspondence: razvanbologa@ase.ro; Tel.: +40-21-319-1900
}

Received: 11 October 2017; Accepted: 29 November 2017; Published: 4 December 2017

\begin{abstract}
This article describes a process for introducing modern technological subjects into the academic curricula of non-technical universities. The process described may increase and contribute to social sustainability by enabling non-technical students' access to the field of the Internet of Things and the broader Industry 4.0. The process has been defined and tested during a curricular reform project that took place in two large universities in Eastern Europe. In this article, the authors describe the results and impact, over multiple years, of a project financed by the European Union that aimed to introduce the following subjects into the academic curricula of business students: cloud computing, big data, mobile programming, and social networks and cybersecurity (CAMSS). The results are useful for those trying to implement similar curricular reforms, or to companies that need to manage talent pipelines.
\end{abstract}

Keywords: cloud computing; big data; social networks; mobile programming; cybersecurity; curricular content and innovation diffusion; constructionism

\section{Introduction}

Employability is currently highly topical as levels of unemployment amongst the younger European generation are increasingly problematic [1]. Employability is defined as "the individual capability to gain employment, to maintain employment, or to replace an employment relationship by another, if necessary or wanted" [2]. The "destruction of jobs" is often blamed on technological evolution. Computers and robots are destroying and supplanting old jobs, which produces unemployment [3].

To sustain the employability of younger generations, it is vital to avoid providing them with obsolete professional competencies [4]. In this article, the authors present a process for modernizing the curricula of non-technical academic programs (e.g., business and finance) to allow non-technical students to learn advanced computing technologies.

In the current literature [5,6], the Internet of Things and Industry 4.0 are subjects with high levels of interest. The predicted changes in the labor market indicate future job requirements and how the employment landscape is supposed to change dramatically in the coming years because of computing technologies. It is expected that advanced skills in cloud computing, big data, mobile programming, and social networks and cybersecurity (CAMSS) will be required by many future jobs.

To react to these forthcoming changes in the labor market, technical universities have already started to provide learning factories and lean labs to their students to begin preparing the workforce required by Industry 4.0 [7]. However, to sustain the access of non-technical students to the labor 
market, non-technical universities will have to insert technical subjects into their curricula. This is quite a challenge, as students of non-technical universities (such as business and finance) are not always interested in learning about sophisticated computing technologies.

In our approach, a technical university is a higher education institution where "the final achievement is a civil engineer degree" [8]. This perception is quite common in Eastern Europe. A non-technical university is one that offers non-engineering degrees to students [8]. In our research, we focused on the particular case of non-technical institutions as all educational programs we analyzed offered a degree in business and economics.

The fact that old industrial jobs will eventually be completely replaced by computers, and future generations will have to work with complex technologies has been both predicted and expected for a long time. The Third Wave, as defined by Toffler [9], has been underway for decades, and is producing profound societal changes across the globe. The third industrial revolution was based on computers and manufacturing robots [10]. The fourth industrial revolution, however, will be based on cyber-physical systems [11]. Please refer to Figure 1 below for a graphical representation of the four industrial revolutions.

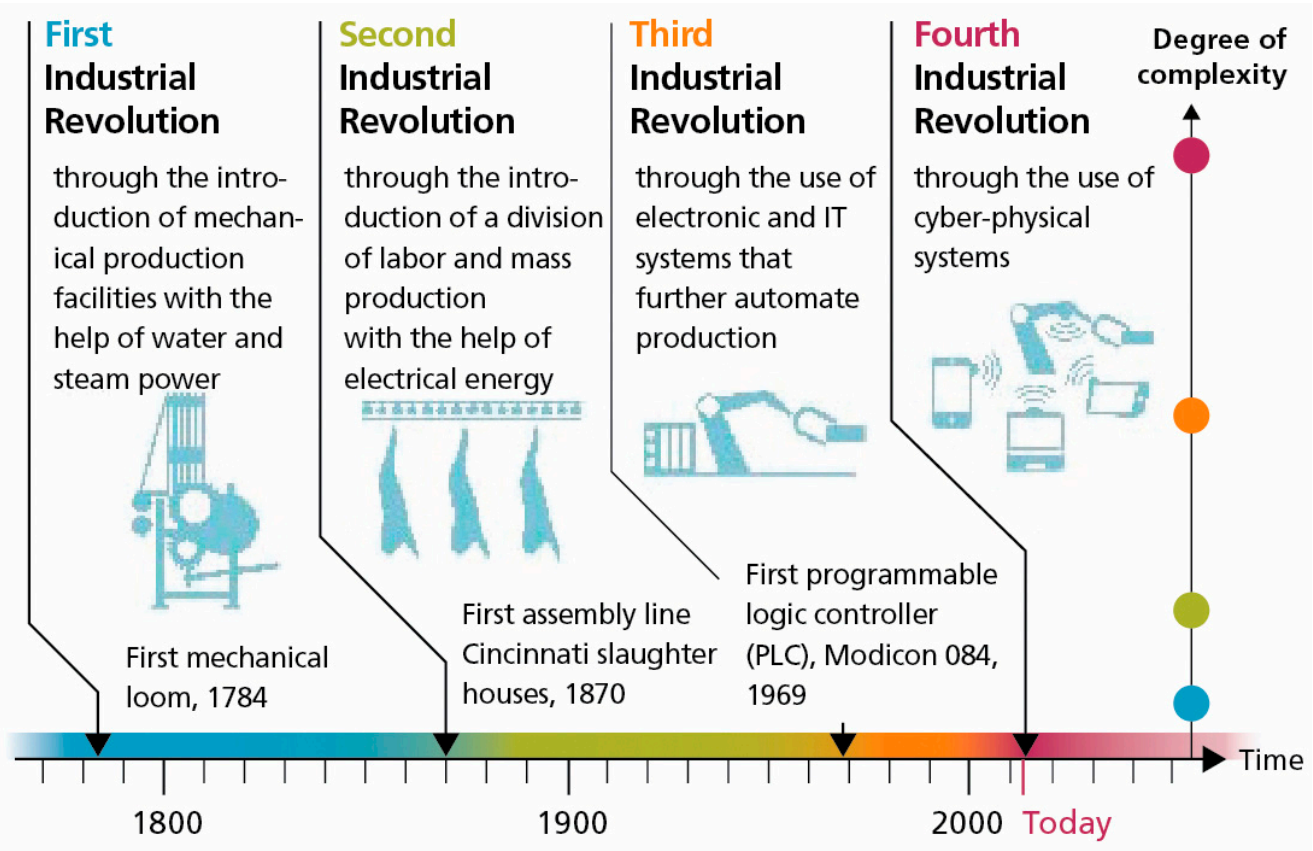

Figure 1. The four industrial revolutions. Source: German Center for Artificial Intelligence [12].

The drivers of change are multiple, and developments in the areas of cloud computing, big data, the Internet of things, artificial intelligence, machine learning, smart systems and robotics are just a few of those worth mentioning [5]. Many traditional, industrial jobs are being lost because workers are being replaced by cyber-physical systems and advanced software, and, in the future, even more jobs will disappear [13]. However, new jobs will appear and they will be based on new technologies and require new skills [14]. The current workforce must adapt and train its skills and knowledge for the changes of Industry 4.0, or otherwise encounter difficulties in meeting the requirements of new jobs [15].

"The speed of current breakthroughs has no historical precedent" [5], and universities have an essential role in helping us as a global society to adapt to the fourth industrial revolution (Industry 4.0). They must identify key domains, extract essential information and incorporate this new approach into the curricula it offers. This is by no means an easy process. Current possibilities "will be multiplied by emerging technology breakthroughs in fields such as artificial intelligence, robotics, the Internet 
of Things, autonomous vehicles, 3-D printing, nanotechnology, biotechnology, materials science, energy storage, and quantum computing" [5].

Apart from the abovementioned competencies, skills such as making adequate prognoses are considered to be important in the context of Industry 4.0 [16]. In addition, Pfeiffer [17] analyzed the impact of the fourth industrial revolution on work (in general), supporting the idea that future employees need to be creative. To support the development of creativity, the educational theory of constructionism was employed into our methodology. Further details on this are available in the next section.

Several other research results that are available in the current literature [18-20] influenced the choices we made in designing the current curricular reform process. According to Hamiti and Wydler [18], it is better to have of a "participatory bottom-up process", which we adopted. The process consists in initiating discussions between diverse groups of professors, researchers and other stakeholders to develop harmonized curricula.

In Bertschy et al. [19], we found two proposed models for profession-specific core competencies: Curriculum, Sustainable Development, Competences, and Teacher Training (CSCT Model); and Learning for the future: The Competences in Education for Sustainable Development (ECE Model). Based on the principles of the ECE Model, we decided to involve social partners in education rather than limiting curricular development to professors.

Another ingredient of an effective education for Industry 4.0 is entrepreneurial spirit [20]. In the current study, we considered it necessary to improve the entrepreneurial skills of the students. This involved enlarging the team of experts beyond the classical working groups of professors to have individuals with entrepreneurial abilities involved in the development of the curricula. Corporate subject matter experts were also invited to participate in the project.

Industry 4.0 is a concept that was developed in Germany and represents an equivalent for the American concept of the Internet of Things (IoT) [21]. The term is popular in Europe. There is a certain degree of consensus that the new Industry 4.0 period will require well-educated employees that can make complex interdisciplinary connections to solve the non-structured problems that they will face [22].

In this article, we will describe a process for incorporating modern tech subjects in the curricula of non-technical universities. Such a process is important because universities are institutions that can help people to adapt to these new jobs. In our opinion, the speed of adapting the academic process must keep up with changes in the labor market. However, the changing of university curricula is hardly expected to be a quick process. Our objective in this article is to present a process for curricular reform that has been successfully tested.

In 2014, two large universities from Eastern Europe received a grant from the European Union to modernize their curricula. The project lasted for 12 months, and the objective of the project was to produce curricular content in the areas of cloud computing, big data, social networks, mobile programming, knowledge management, and digital commerce. Although it was not part of the initial project, curricular content in the area of cybersecurity was also produced, albeit on a smaller scale.

The project was named "Developing and modernizing the curricula in business information systems" (DEZIE). It was one of the first projects in Eastern Europe financed by the European Union aiming to develop and implement modern curricular content oriented towards cloud computing, big data, social networks and cybersecurity; the project started in June 2014 and ended in May 2015. The main partner of the project was the Bucharest University of Economic Studies, supported by the West University of Timisoara and a local, medium sized private company. Both universities are non-technical and the curricula were designed for educational programs in business, finance, and economics.

The main objectives of the project were: (a) to develop up-to-date curricula for CAMSS and related domains; (b) to teach these new curricula to a significant group of students as non-mandatory 
free classes; and (c) to use the feedback gathered from students, workshop participants and experts to implement the materials developed as official curricula in the Faculty of Economic Cybernetics, Statistics and Informatics.

To achieve the objectives above, in addition to management and administrative teams, there were 40 academic teachers who directly participated in developing new curricula and/or teaching it to the student target groups. Beyond this, another 59 academic teachers from 13 universities facilitated the development of DEZIE and spread the new curricula at their universities. As mentioned above, collaboration with companies was very important for the success of the project; therefore, 22 members of 15 companies helped the team of professors to provide higher quality curricula. Most of the tech giants were part of the workshops of the project. These included names such as Google, IBM, Microsoft, Oracle, Dell, and SAP.

To ensure a good level of quality, the new curricula were taught to a group of 210 students, selected from more than 400 applicants. The 210 students were divided into three groups: two of them attended courses at the Bucharest University of Economic Studies, and the third at the West University of Timisoara.

Curricular materials were divided into six categories:

1. Cloud computing, big data analytics

2. Mobile programming

3. Social networks

4. Knowledge management

5. Digital commerce.

All curricular materials were made available to professors at targeted educational programs and were proposed for implementation. The incorporation of the new curricula was not mandatory and faculty members had to understand the advantages of the new curricula to adopt it.

\section{Problem Formulation}

How do you introduce technical subjects, such as cloud computing and big data, into the curricula of non-technical undergraduate and master's university programs, such as business, finance, statistics, marketing, and other similar programs? This was the starting point of our research. It was quite a challenge to define a curriculum, because non-technical students tend to avoid technical subjects [23]; however, such subjects are essential for their professional success in a world based on cyber-physical systems.

A detailed interpretation of the results, based on statistical analyses, is available to the reader in the Results section. The data were obtained during the implementation process and by monitoring the academic community during the post-implementation period. The results of the statistical analysis show the actual adoption rate of the new proposed curricula by faculty members from the targeted educational programs.

\section{Methodological Approach}

The methodology used in this article had three components: the learning paradigm, data collection methods, and the data analysis model. To design and test the process described in the current article, we have combined the three methodological elements specified above.

The intellectual roots of our psycho-pedagogical approach go back to Seymour Papert, a former professor at the Massachusetts Institute of Technology. Our process for modernizing academic curricula has constructionism as a theoretical foundation. Constructionism is a well-known learning paradigm that was proposed by Seymour Papert in the 1980s [24].

Constructionism is an evolution of constructivism and was proposed by Seymour Papert to cover the need for a learning theory suitable for learning computer science at an early age. In Papert's vision, “constructionism—-the $\mathrm{N}$ word as opposed to the V word-shares constructivism's connotation of 
learning as 'building knowledge structures' irrespective of the circumstances of the learning. It then adds the idea that this happens especially felicitously in a context where the learner is consciously engaged in constructing a public entity, whether it's a sand castle on the beach or a theory of the universe" [25].

In constructionism, one starts from the idea that building objects and designing programs are activities that create a good context for learning [26]. The knowledge of the learner is extended by participating in various experiences that are offered as a way of learning. The education process is centered on the learner, and each learner "constructs" his or her own understanding of reality.

Following the principles of constructionism, our process for modernizing the curricula has a bottom-up approach. The following steps are part of the methodology for creating new curricular content:

(a) Select a group of professors that are interested in the subject.

(b) Create groups for each subject based on individual interests.

(c) Create a common working environment, such as an e-learning platform or a wiki.

(d) Place the content online.

(e) Discuss the content in several workshops with other professors and company representatives.

(f) Test the new curricular content on many students.

(g) Get feedback from the students.

(h) Integrate the feedback of the students.

(i) Create reports for each curricular area.

(j) Distribute the reports and disseminate the new content to professors that were not part of the process.

A fundamental principle of our approach was that the new curricular content should be public while it was under development. The professors and professionals who contributed to the curricula were required to work in a public environment where everybody could see the work while it was being developed. This is in line with the basic principles of constructionism.

The data were collected during the project and for a period of two years after implementation. The authors collected data about the level of penetration of CAMSS subjects into the academic curricula before the project.

IBM, among other IT companies, consider cloud computing, analytics, mobile, social, and security, to be important topics in the Fourth Industrial Revolution [27]. In this article, the authors included all courses where CAMSS topics were present in the curricula. The authors divided CAMSS topics in two groups: light and core. The light CAMSS category includes the following topics: Social networks, cloud computing, business intelligence, and digital commerce. The core CAMSS category contains the following: Mobile programming, big data, and cybersecurity (CAMSS).

\section{The Process}

The total project duration was one year (12 months) and covered six curricular areas. The process involved 61 experts (short term and long term), 20 company representatives, 45 professors, four technical staff members, and 210 students. The experts, professors, and students came from the two universities that were partners in the project.

Figure 2 explains in detail the process followed during the implementation of the curricular reform project. Each step is explained in detail in this section. To replicate the process in another environment, one has to follow the steps of the process to understand and take into consideration the concepts behind each step.

Step 1: Selection of experts

In the first step of the process, we selected a team of 61 professors from two universities that agreed to join the project and develop the curricula. The selection of the professors was made on 
a voluntary basis. They were hired as experts in the project with contract durations ranging from three months to one year. The manager of the project defined six curricular areas and assigned each professor to one of the curricular areas. Each curricular area had one coordinator responsible for the integration of curricular development.

The curricular areas were chosen based on input from the large employers that participated in the process. Partner companies, such as IBM, Oracle, SAP and Microsoft, shared their visions of the future labor market. After collating the data, we decided to focus on the following curricular areas: Cloud computing, big data (analytics), social networks, mobile programming, knowledge management, and digital commerce. A cybersecurity curriculum was also developed outside of the EU-funded project, and it is for this reason that it was monitored in the current research.

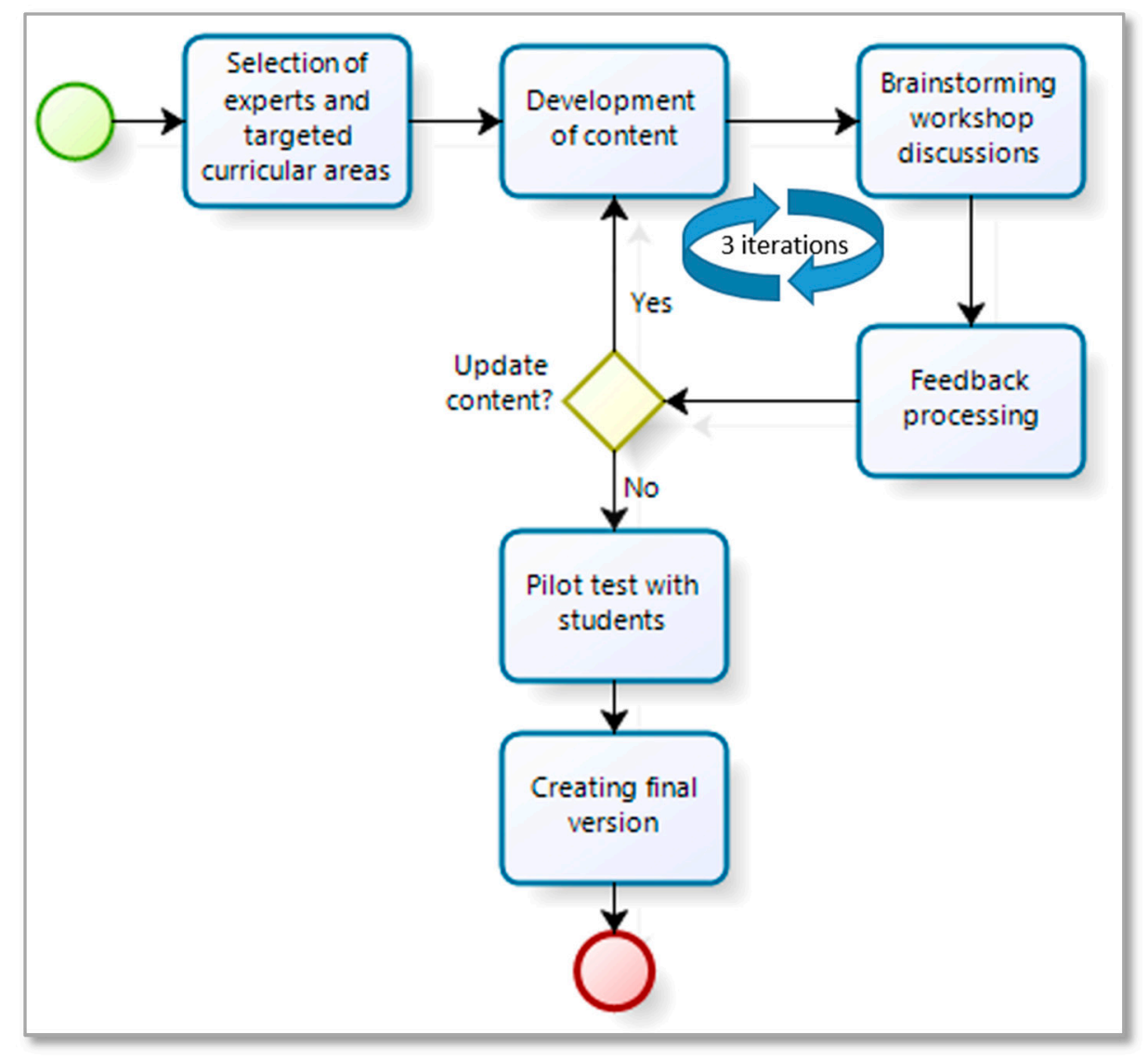

Figure 2. Presentation of the main steps of the curricular reform process.

Experts that were hired as short-term experts (three months) only participated in the first part of the process. About $80 \%$ of the experts from the working group were professors, while $20 \%$ were corporate subject-matter experts. The short-term experts contributed to the first version of the curricular content. These experts were involved only in the creation of the first version of the curricular content when a large amount of work was required. Their activity was limited to this phase to minimize costs. Other experts were hired as long term experts (one year) and they were responsible for the integration of the components of the process through the various steps of the project.

Step 2: Development of content

For developing the content, an e-learning platform was set-up. The main purpose of the e-learning platform was to allow all experts to post their work online and for the others to see it. For a constructionist approach, it is essential to publicly show results during the project and afterwards. The platform we used was an open-source application. 
The learning platform was divided into sections; each section corresponding to a curricular area. For each curricular area, the experts were asked to develop 12 different sub-sections, plus a set of verification questions. The title of each sub-section was decided by the coordinator of the section together with the project manager.

According to the plan and the budget of the project, the experts had a period of three months to develop the first version of the content. During this time, they developed both theoretical and practical curricular content. The first version of the curricular content was not discussed with people outside of the team of experts.

\section{Step 3: Brainstorming workshops}

To integrate different perspectives, three workshops with outside experts were organized. The main purpose of the workshops was to allow relevant experts to provide feedback regarding the curricula. Two of the workshops were organized with professors, while the third was organized with subject matter experts from companies. The subject matter experts were different to the experts that were hired in the project; these were volunteers that were willing to review the curricular content that was developed by the experts.

The workshops were organized based on the brainstorming method. Participants were asked to spend some time analyzing the curricular content that was developed; after that, they gathered around a table and the project manager, together with the long-term experts, asked each of the invited experts for ideas on improving the curricular content.

The objective of this exercise was to obtain feedback, comments, suggestions and creative opinions regarding new topics and/or technologies that could be added to the curricula. The invited experts were encouraged to express new ideas freely. Each idea and suggestion was written down without being commented on during these group discussions.

The workshops lasted one day. Over the course of the day, two sessions were organized. Informal discussions between the workshops were of great help as they allowed experts to talk face to face in a relaxed manner. The session with corporate experts was more limited in time due to the limited availability of the participants.

Step 4: Feedback processing

At the end of each workshop, the project manager processed the feedback with the long-term experts. Since ideas were expressed freely, they were not limited to a certain curricular area. This is why relevant ideas, suggested during the brainstorming workshops, had to be allocated to a proper curricular area.

For each suggestion that was considered valid, long-term experts invested time and effort to integrate it into the curriculum. The list of valid ideas was created based on a voting system. Any suggestion that was supported by at least three persons was included in the list. At this stage, only the long-term experts were involved. Occasionally, a few short-term experts were also allowed to be part of the process; however, in order to avoid confusion, each new suggestion was assigned to only one expert for one curricular area.

The workshops were organized such that there was one workshop every five weeks. This allowed organizers time to integrate the feedback as well as to perform necessary administrative activities in order to organize the workshops.

The process of updating the curricula based on the feedback of the invited experts was an interactive and repetitive one. There were three iterations of the process, each of them corresponding to a separate workshop. In each workshop there were six groups, one per each curricular area. The discussions were at group level with an opening session that involved all participants. The curricular content was only updated according to the opinions of the invited experts and the long-term experts were instructed to make changes at this stage. 
By repeating the discussions related to curricular content with numerous external experts, the members of the project had the opportunity to integrate any number of fresh perspectives, from both academics and corporate executives.

Step 5: Pilot test with students

The pilot test with students was an important part of the process. It was good chance for the experts to be able to actually teach the content to a number of students. There were 210 students selected to be part of the process- they came from two universities and were divided into five groups. To make the competition attractive, the students were offered prizes. A total of 30 high-end bicycles were given away as prizes to the best students.

The pilot test with students included $28 \mathrm{~h}$ of educational activities for each group of students. The 210 students were divided into 10 groups of 21 students, and each group was asked to study the content of two different curricular areas. At the end, we organized a test to assess the progress of the students. The prizes were given to the students with the highest scores in each group.

Step 6: Creating a final version

The last step of the process was integrating the feedback from the students. The long-term experts oversaw collecting feedback from students and interpreting it. Most of the students offered feedback related to the practical side of the curriculum. This was valuable, as during the workshops, the feedback received was mostly related to the theoretical dimension of the curriculum.

Based on the feedback of students, experts created the final version of the curriculum; this version was uploaded online. For each curricular area, experts created a report that synthetized the developed curriculum. The reports were printed and distributed in an easy-to-read format to a list of interested professors.

The newly-developed curricula maintained a focus on the foundations of computing, while supporting the process of teaching information technology and computer science to non-technical students. Most of the students that participated in Step 5 did not have a technical background. However, most of the subjects introduced in the curricula were of a technical nature.

During the pilot test, students were encouraged to think critically and creatively, based on new technologies. It was pointed out to the students that they were not being encouraged to focus only on the technology itself; they were being encouraged to reach an ability level which would enable them to use these new technologies to increase their capacity to be creative and critical thinkers.

The process was tested during a period of 12 months at two universities from Eastern Europe: The Bucharest University of Economic Studies and the West University of Timisoara. The new curricula began to be adopted by various departments from the participating universities and from other universities in the region.

Contact with students was an important ingredient in our attempt technical subjects to the curricula of non-technical students. To replicate the process, interested authors must follow the steps described above as well as observe the methodological principles from the previous section.

\section{Results and Discussions}

As a result of implementing the curricular reform project, a substantial number of undergraduate and graduate programs of the two partner universities were updated. The process of gathering the data and monitoring the impact was a natural continuation of the six steps presented above. However, it was not financed from the project funded by the European Union and it was performed for a period of two years after implementing the project. CAMSS components were inserted into the curricula of both undergraduate and master's degree programs. This section presents data obtained in the process and provides a synthesis of the situation, before and after the project implementation. 
The data gathered compare the educational program curricula from the academic year 2013-2014 with curricula for 2017-2018, before and after project implementation. We gathered data for the educational programs where project experts acted as professors.

As pointed out below, the authors considered the present project to be an important driver of change, not only because quality curricula were created and ready to be used, but also because a significant number of academic professors were involved and they become familiar with the new curricula during the project.

\subsection{Impact on Undergraduate Programs}

The authors gathered data from 10 undergraduate educational programs, from both partners of the universities, for the academic year 2017-2018. Table 1 shows the distribution of CAMSS courses per years of study, and the percent of CAMSS courses relative to total courses, as well as general information about the total number of courses for each program.

Table 1. CAMSS courses in undergraduate programs in 2017-2018.

\begin{tabular}{|c|c|c|c|c|c|c|c|c|c|c|}
\hline \multirow[b]{2}{*}{$\begin{array}{l}\text { Name of } \\
\text { University }\end{array}$} & \multicolumn{10}{|c|}{ Undergraduate Degree } \\
\hline & $\begin{array}{c}\text { Educational } \\
\text { Program }\end{array}$ & $\begin{array}{l}\text { Year } \\
\text { of } \\
\text { Study }\end{array}$ & $\begin{array}{l}\text { Mandatory } \\
\text { Courses }\end{array}$ & $\begin{array}{c}\text { Optional } \\
\text { Courses }\end{array}$ & $\begin{array}{l}\text { Additional } \\
\text { Courses }\end{array}$ & $\begin{array}{l}\text { Total } \\
\text { Courses }\end{array}$ & $\begin{array}{c}\text { Light } \\
\text { CAMSS }\end{array}$ & $\begin{array}{l}\text { Core } \\
\text { CAMSS }\end{array}$ & $\begin{array}{c}\text { Total } \\
\text { CAMSS }\end{array}$ & $\begin{array}{l}\text { CAMSS } \\
\text { Percent }\end{array}$ \\
\hline \multirow{32}{*}{ 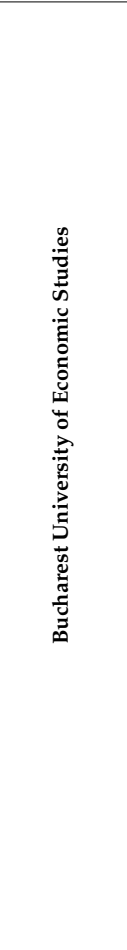 } & \multirow{4}{*}{$\begin{array}{l}\text { Accounting } \\
\text { and } \\
\text { management } \\
\text { information }\end{array}$} & I & 12 & 8 & 9 & 29 & 0 & 0 & 0 & $0.00 \%$ \\
\hline & & II & 13 & 2 & 8 & 23 & 2 & 0 & 2 & $8.70 \%$ \\
\hline & & III & 13 & 4 & 4 & 21 & 2 & 0 & 2 & $9.52 \%$ \\
\hline & & Total & 38 & 14 & 21 & 73 & 4 & 0 & 4 & $5.48 \%$ \\
\hline & \multirow{4}{*}{$\begin{array}{c}\text { systems } \\
\text { Business } \\
\text { administration } \\
\text { (FABIZ) }\end{array}$} & I & 12 & 7 & 7 & 26 & 2 & 0 & 2 & $7.69 \%$ \\
\hline & & II & 16 & 7 & 8 & 31 & 1 & 0 & 1 & $3.23 \%$ \\
\hline & & III & 15 & 0 & 0 & 15 & 0 & 0 & 0 & $0.00 \%$ \\
\hline & & Total & 43 & 14 & 15 & 72 & 3 & 0 & 3 & $4.17 \%$ \\
\hline & \multirow{4}{*}{$\begin{array}{l}\text { Business and } \\
\text { Tourism }\end{array}$} & I & 14 & 6 & 9 & 29 & 1 & 0 & 1 & $3.45 \%$ \\
\hline & & II & 13 & 13 & 9 & 35 & 1 & 0 & 1 & $2.86 \%$ \\
\hline & & III & 13 & 12 & 10 & 35 & 0 & 0 & 0 & $0.00 \%$ \\
\hline & & Total & 40 & 31 & 28 & 99 & 2 & 0 & 2 & $2.02 \%$ \\
\hline & \multirow{4}{*}{$\begin{array}{l}\text { Business } \\
\text { Information } \\
\text { Systems }\end{array}$} & $\mathrm{I}$ & 17 & 0 & 0 & 17 & 0 & 0 & 0 & $0.00 \%$ \\
\hline & & II & 15 & 9 & 4 & 28 & 0 & 0 & 0 & $0.00 \%$ \\
\hline & & III & 14 & 4 & 0 & 18 & 3 & 1 & 4 & $22.22 \%$ \\
\hline & & Total & 46 & 13 & 4 & 63 & 3 & 1 & 4 & $6.35 \%$ \\
\hline & \multirow{4}{*}{$\begin{array}{l}\text { Economic } \\
\text { Computation }\end{array}$} & I & 17 & 0 & 0 & 17 & 0 & 0 & 0 & $0.00 \%$ \\
\hline & & II & 15 & 9 & 4 & 28 & 0 & 0 & 0 & $0.00 \%$ \\
\hline & & III & 14 & 4 & 0 & 18 & 3 & 0 & 3 & $16.67 \%$ \\
\hline & & Total & 46 & 13 & 4 & 63 & 3 & 0 & 3 & $4.76 \%$ \\
\hline & \multirow{4}{*}{$\begin{array}{l}\text { International } \\
\text { Business and } \\
\text { Economics }\end{array}$} & I & 14 & 12 & 2 & 28 & 1 & 0 & 1 & $3.57 \%$ \\
\hline & & II & 13 & 12 & 16 & 41 & 0 & 0 & 0 & $0.00 \%$ \\
\hline & & III & 7 & 34 & 11 & 52 & 0 & 0 & 0 & $0.00 \%$ \\
\hline & & Total & 34 & 58 & 29 & 121 & 1 & 0 & 1 & $0.83 \%$ \\
\hline & \multirow{4}{*}{ Marketing } & I & 14 & 1 & 9 & 24 & 1 & 0 & 1 & $4.17 \%$ \\
\hline & & II & 14 & 12 & 11 & 37 & 1 & 0 & 1 & $2.70 \%$ \\
\hline & & III & 16 & 7 & 13 & 36 & 3 & 0 & 3 & $8.33 \%$ \\
\hline & & Total & 44 & 20 & 33 & 97 & 5 & 0 & 5 & $5.15 \%$ \\
\hline & \multirow{4}{*}{$\begin{array}{l}\text { Statistics and } \\
\text { Economic } \\
\text { Forecasting }\end{array}$} & I & 17 & 0 & 0 & 17 & 0 & 0 & 0 & $0.00 \%$ \\
\hline & & II & 15 & 9 & 4 & 28 & 0 & 0 & 0 & $0.00 \%$ \\
\hline & & III & 14 & 4 & 0 & 18 & 1 & 1 & 2 & $11.11 \%$ \\
\hline & & Total & 46 & 13 & 4 & 63 & 1 & 1 & 2 & $3.17 \%$ \\
\hline \multirow{8}{*}{ 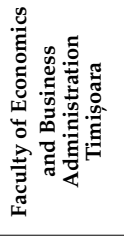 } & \multirow{4}{*}{$\begin{array}{l}\text { Management } \\
\text { (FEEA, UVT) }\end{array}$} & I & 14 & 4 & 5 & 23 & 1 & 0 & 1 & $4.35 \%$ \\
\hline & & II & 14 & 4 & 6 & 24 & 0 & 0 & 0 & $0.00 \%$ \\
\hline & & III & 11 & 8 & 6 & 25 & 1 & 0 & 1 & $4.00 \%$ \\
\hline & & Total & 39 & 16 & 17 & 72 & 2 & 0 & 2 & $2.78 \%$ \\
\hline & \multirow{4}{*}{$\begin{array}{l}\text { Finance and } \\
\text { Banking } \\
\text { (FEEA, UVT) }\end{array}$} & $\mathrm{I}$ & 14 & 4 & 5 & 23 & 1 & 0 & 1 & $4.35 \%$ \\
\hline & & II & 18 & 6 & 6 & 30 & 0 & 0 & 0 & $0.00 \%$ \\
\hline & & III & 17 & 2 & 6 & 25 & 1 & 0 & 1 & $4.00 \%$ \\
\hline & & Total & 49 & 12 & 17 & 78 & 2 & 0 & 2 & $2.56 \%$ \\
\hline \multirow{4}{*}{\multicolumn{2}{|c|}{ Overall results }} & $\mathrm{I}$ & 128 & 42 & 46 & 216 & 7 & 0 & 7 & $3.24 \%$ \\
\hline & & II & 146 & 74 & 72 & 277 & 5 & 0 & 5 & $1.81 \%$ \\
\hline & & III & 120 & 75 & 50 & 245 & 13 & 1 & 14 & $5.71 \%$ \\
\hline & & Total & 425 & 191 & 168 & 738 & 25 & 1 & 26 & $3.52 \%$ \\
\hline
\end{tabular}

The percent of average CAMSS topics, out of all topics, by years were: $2.76 \%$ for first year, $1.75 \%$ for the second, and $7.59 \%$ for the third year. The value for the third year was considerably higher than the values of the first two years, showing a greater concern for modern, IT-specialized subjects 
that are appreciated by employers after completing their studies. As stated before the light CAMSS category includes the following topics: Social networks, cloud computing, business intelligence, and digital commerce. The core CAMSS category contains the following: Mobile programming, big data, and cyber security (CAMSS).

Most of the CAMSS courses are light CAMSS types (26 in total), compared to only two core CAMSS courses (see Figure 3 for their distribution per studied undergraduate program); the total CAMSS percent is quite low, and the core CAMSS percent is almost zero (Figure 4). This result confirms that light CAMSS courses were adopted at a better rate than core CAMSS courses. This result shows that it is possible to provide students some knowledge of CAMSS, even at an undergraduate level. During the initial discussions at project kick-off, a group of five short-term experts participating in the project advocated the idea of limiting CAMSS content to the master's level. The reason they presented was the fact that CAMSS subjects' learning curve was too steep for undergraduate students in economics. However, promising results of the project seem to indicate that it is also possible to provide a basic knowledge of CAMSS at an undergraduate level.

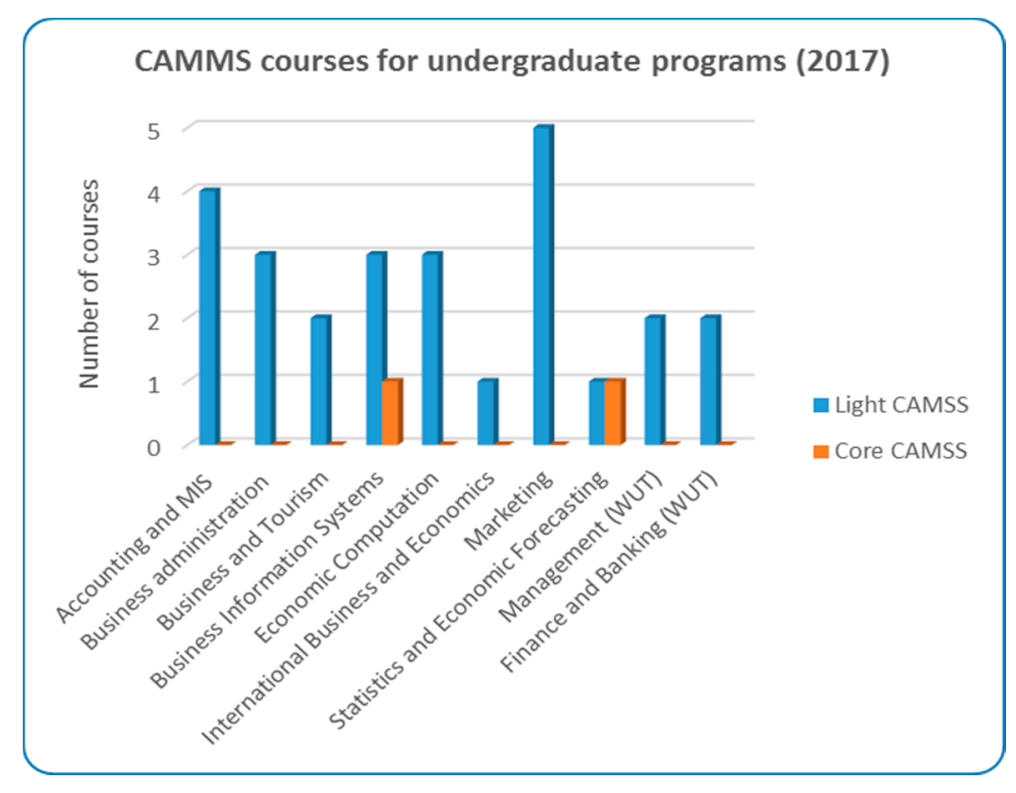

Figure 3. Percent of CAMSS courses for undergraduate degree programs, detailed by light/core.

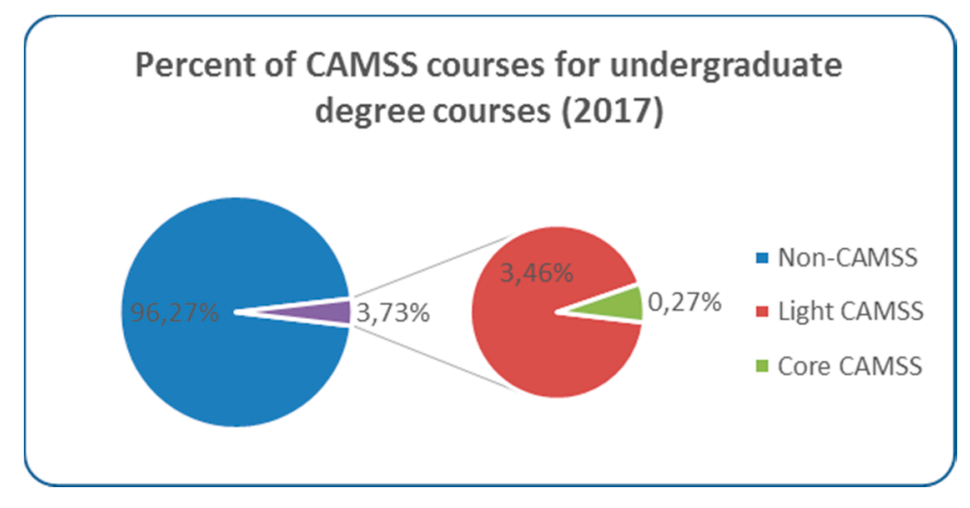

Figure 4. CAMSS courses for studied undergraduate degree programs in 2017.

To obtain a better view of the efficiency of our curricular reform process, we performed a comparative analysis of the number of CAMSS courses, before and after the implementation of the project. The data are shown in Table 2. 
Table 2. Comparison of CAMSS course in undergraduate's degree curricula before and after 2014.

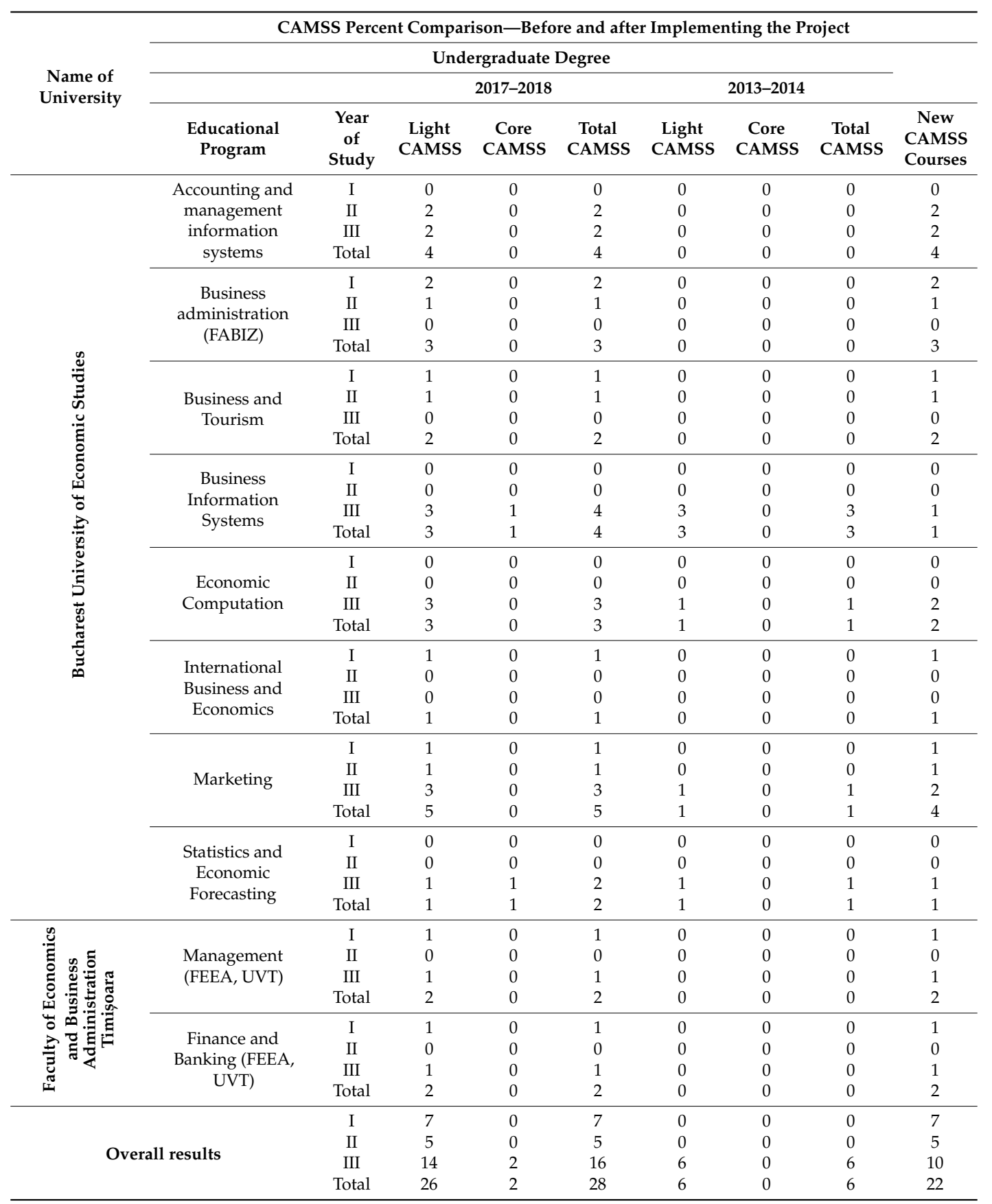

At the beginning of the project, the targeted undergraduate programs contained only six CAMSS courses, all of them in the third year of study. The project started in the academic year 2013-2014. After the implementation of the project, the situation has changed. In the academic year 2017-2018, the targeted educational programs contained 28 CAMSS topics. The distribution per year is as follows: seven in the first year of study, five in the second and 16 in the third.

The results in Table 2 show a major improvement in the educational programs that were targeted by the curricular reform project. In only three years, the number of CAMSS courses in the educational programs (that involved professors that participated in the curricular reform project) multiplied by four, as illustrated in Figure 5. 


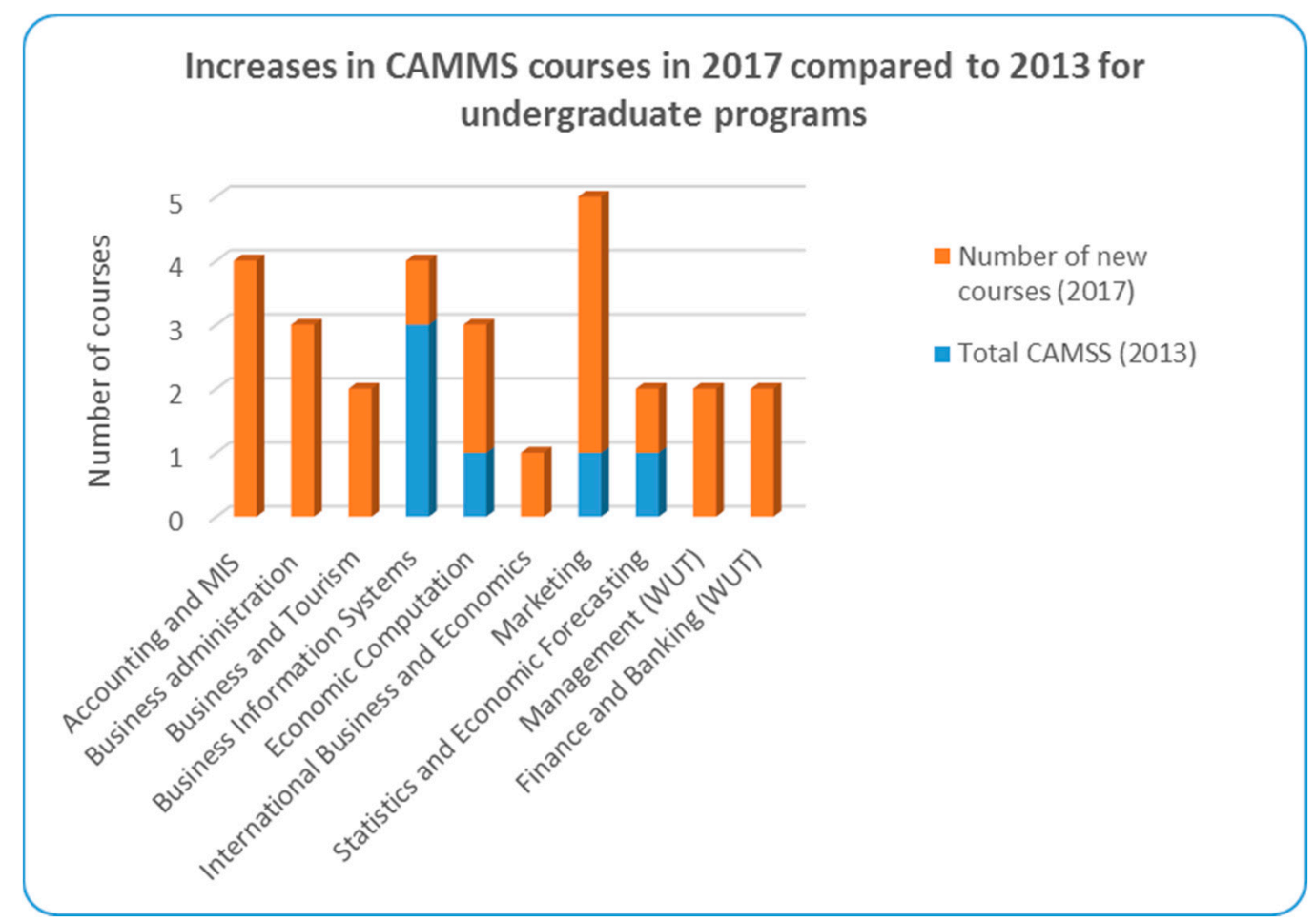

Figure 5. Increases in the number of CAMSS courses for undergraduate programs in 2017 compared to 2013.

It is important to remark that the availability of high-quality documentation, and the involvement of professors in the process of changing the curricular content had an important positive impact on the structure of existing courses and on the adoption of new CAMSS courses.

The professors that participated in workshops come from different educational programs to the two universities that took part in the curricular reform project. Figure 6 presents the structure of the professors from the first university grouped by educational program. The same information is available in Figure 7, for the professors coming from the second university.

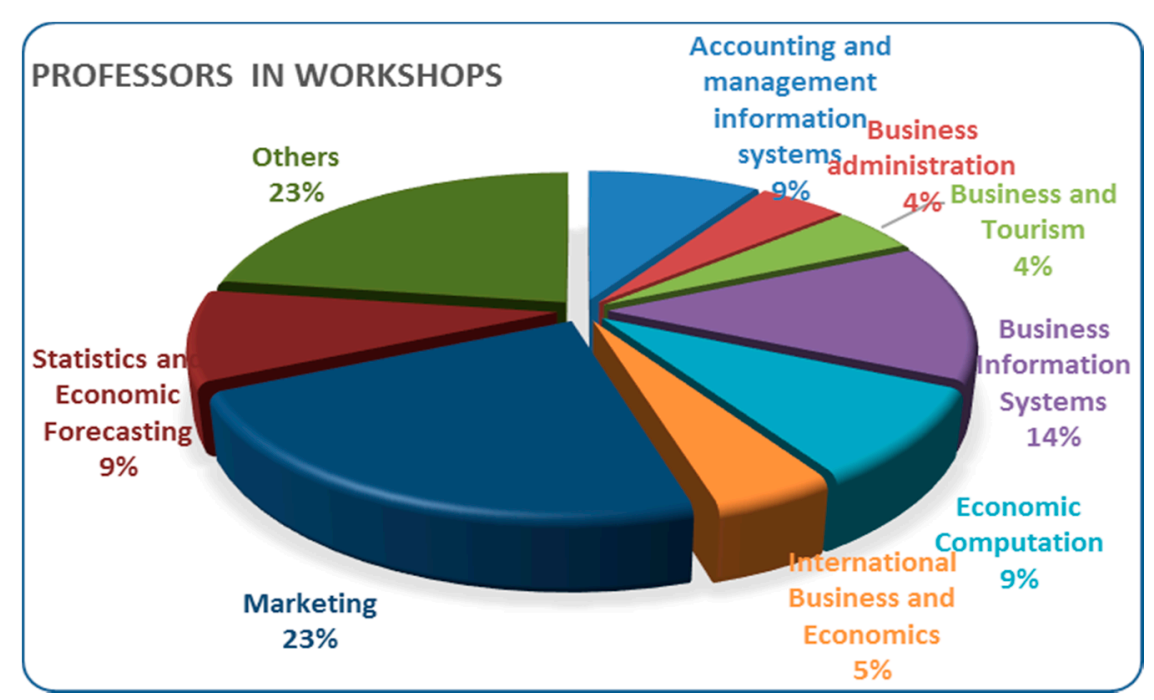

Figure 6. Structure of the group of professors that participated in the workshops-Bucharest University of Economic Studies. 


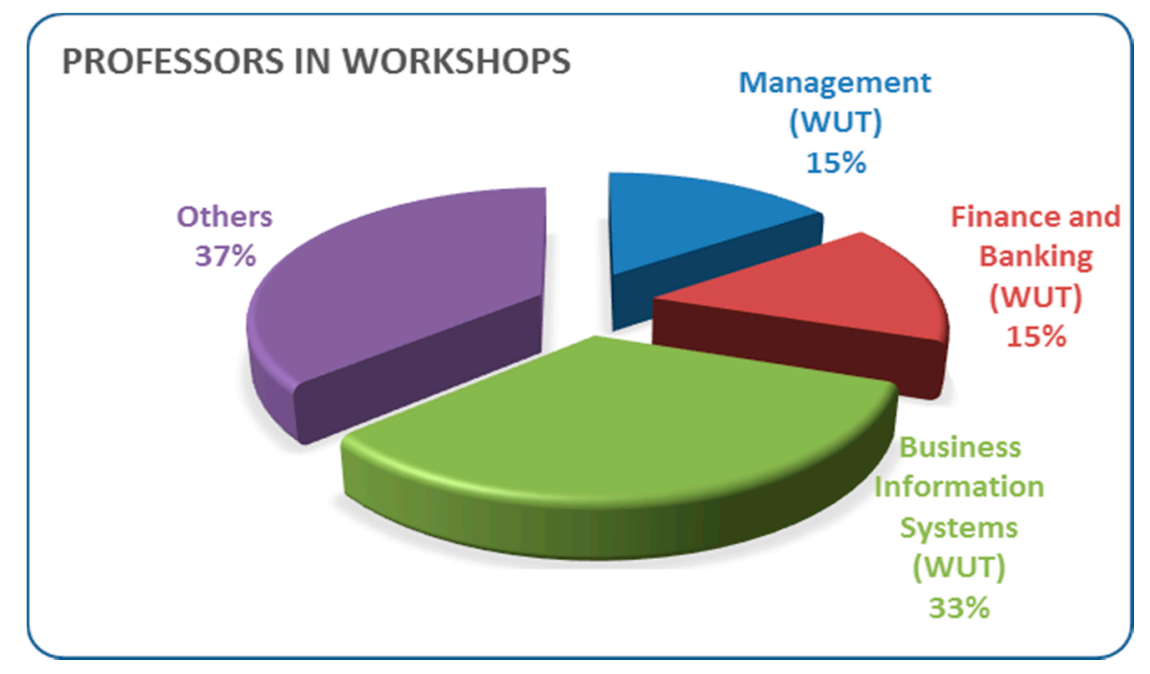

Figure 7. Breakdown of the group of professors that participated in the workshops-West University of Timisoara.

We will make a comparative analysis between the structure of the professors that participated in the workshops and the structure of the modifications of the educational programs. By comparing the data in Figure 5 with the data in Figures 6 and 7, we can see a certain correlation between the structures of these groups and the most significant increases in CAMSS adoption.

For example, the marketing department, which had the highest number of professors involved in the workshops, added four new CAMSS courses, similarly to the accounting department, which provided $9 \%$ of workshop professors.

Business administration, finance and business services were also well represented in the workshops. An important number of professors from these departments participated in the workshops. As one can see in Figures 6 and 7, an important number of courses CAMSS courses were introduced in business administration, finance and business services.

There were many professors from the area of business information systems. From the first university, there were $14 \%$ and from the second one there were $33 \%$ coming from the area of business information systems. As we can see in Figure 5, the number of CAMSS courses has increased in this area. However, the rate of increase of CAMSS courses was smaller. The educational programs in this area already had an important number of CAMSS courses before the start of the project.

The professors that participated in the workshops occupied senior positions in their departments. In the selection of participants, we avoided as much as possible the presence of junior members of the faculty staff.

The marketing and the business information systems departments expressed the most interest in participating in the project. Their members joined the workshops in higher percentages than the members of other departments. Management and business administration also had a notable presence.

\subsection{Impact on Master's Degree Programs}

During the current research, we gathered data from 16 master's educational programs, from both universities for the academic year of 2017-2018. Our objective was to observe the curricular changes in the targeted areas of cloud computing, big data, mobile programming, social networks and cybersecurity (CAMSS) courses. Analyzing the curricular changes related to these topics is important because studying CAMSS topics increases the chances of finding good jobs, as discussed in first section of the current article. Table 3 shows the same type of analysis as that presented in Table 2, but this time applied to master's degree educational programs. 
The distribution of CAMSS courses per year is much more balanced for master's educational programs than for undergraduate programs. In the first year of study, this distribution accounted for $23.27 \%$ and it accounted for $16.91 \%$ in the second year, of the topics were CAMSS type courses. Out of a total of 68 CAMSS courses, 44 are light-type CAMSS and 24 are core-type CAMSS and their distributions are not uniform (Figure 8). This led the authors to the conclusion that, being more technical, core CAMSS topics tend to be introduced later in the curriculum, in master's educational programs, when students have already gained basic knowledge.

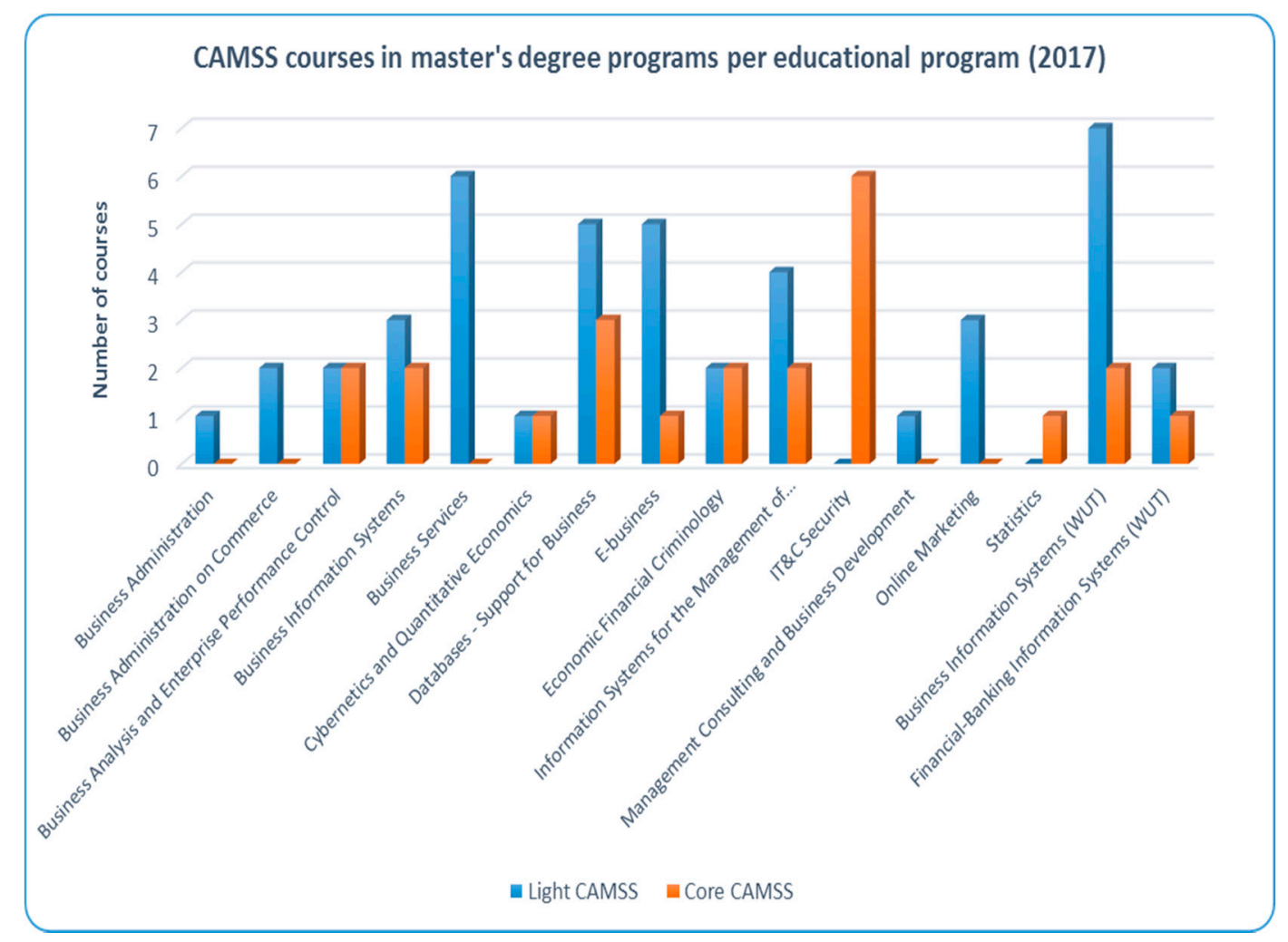

Figure 8. CAMSS courses in master's degree programs per educational program in 2017.

The relatively-high percentage of difficult core CAMSS courses that are shown in Figures 8 and 9 supports the conclusion that the tech curricula should be placed in more business master's programs, as they are more likely to adopt the new curriculum. A possible explanation of this fact could be that these students are closer to the labor market. In the targeted universities, students have much better contact with employers after they finish their undergraduate programs and they start looking for jobs. That is why they are better able to understand the requirements of future jobs, and they are more likely to take over the difficult task of studying the curricula of a core CAMSS course. 
Table 3. CAMSS courses in undergraduate programs in 2017-2018.

\begin{tabular}{|c|c|c|c|c|c|c|c|c|c|}
\hline \multirow{2}{*}{$\begin{array}{l}\text { Name of } \\
\text { University }\end{array}$} & \multicolumn{9}{|c|}{ Master's Degree } \\
\hline & Educational Program & $\begin{array}{l}\text { Year of } \\
\text { Study }\end{array}$ & $\begin{array}{c}\text { Mandatory } \\
\text { Courses }\end{array}$ & $\begin{array}{l}\text { Courses at } \\
\text { Choice }\end{array}$ & $\begin{array}{c}\text { Total } \\
\text { Courses }\end{array}$ & $\begin{array}{c}\text { Light } \\
\text { CAMSS }\end{array}$ & $\begin{array}{c}\text { Core } \\
\text { CAMSS }\end{array}$ & $\begin{array}{c}\text { Total } \\
\text { CAMSS }\end{array}$ & $\begin{array}{l}\text { CAMSS } \\
\text { Percent }\end{array}$ \\
\hline \multirow{42}{*}{ 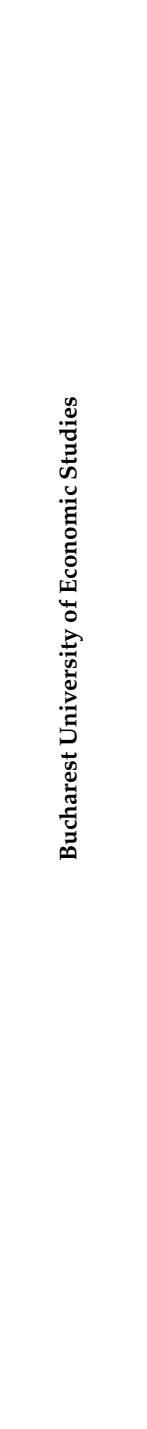 } & \multirow{3}{*}{$\begin{array}{c}\text { Business } \\
\text { Administration }\end{array}$} & $\mathrm{I}$ & 10 & 0 & 10 & 1 & 0 & 1 & $10.00 \%$ \\
\hline & & II & 7 & 0 & 7 & 0 & 0 & 0 & $0.00 \%$ \\
\hline & & Total & 17 & 0 & 17 & 1 & 0 & 1 & $5.88 \%$ \\
\hline & \multirow{3}{*}{$\begin{array}{c}\text { Business } \\
\text { Administration on } \\
\text { Commerce }\end{array}$} & I & 8 & 7 & 15 & 1 & 0 & 1 & $6.67 \%$ \\
\hline & & II & 10 & 0 & 10 & 1 & 0 & 1 & $10.00 \%$ \\
\hline & & Total & 18 & 7 & 25 & 2 & 0 & 2 & $8.00 \%$ \\
\hline & \multirow{3}{*}{$\begin{array}{l}\text { Business Analysis and } \\
\text { Enterprise } \\
\text { Performance Control }\end{array}$} & $\mathrm{I}$ & 8 & 0 & 8 & 1 & 1 & 2 & $25.00 \%$ \\
\hline & & II & 6 & 2 & 8 & 1 & 1 & 2 & $25.00 \%$ \\
\hline & & Total & 14 & 2 & 16 & 2 & 2 & 4 & $25.00 \%$ \\
\hline & \multirow{3}{*}{$\begin{array}{l}\text { Business Information } \\
\text { Systems }\end{array}$} & $\mathrm{I}$ & 9 & 0 & 9 & 1 & 1 & 2 & $22.22 \%$ \\
\hline & & II & 7 & 0 & 7 & 2 & 1 & 3 & $42.86 \%$ \\
\hline & & Total & 16 & 0 & 16 & 3 & 2 & 5 & $31.25 \%$ \\
\hline & \multirow{3}{*}{ Business Services } & $\mathrm{I}$ & 8 & 8 & 16 & 3 & 0 & 3 & $18.75 \%$ \\
\hline & & II & 7 & 7 & 14 & 3 & 0 & 3 & $21.43 \%$ \\
\hline & & Total & 15 & 15 & 30 & 6 & 0 & 6 & $20.00 \%$ \\
\hline & \multirow{3}{*}{$\begin{array}{c}\text { Cybernetics and } \\
\text { Quantitative } \\
\text { Economics }\end{array}$} & I & 8 & 0 & 8 & 0 & 1 & 1 & $12.50 \%$ \\
\hline & & II & 6 & 6 & 12 & 1 & 0 & 1 & $8.33 \%$ \\
\hline & & Total & 14 & 6 & 20 & 1 & 1 & 2 & $10.0 \%$ \\
\hline & \multirow{3}{*}{$\begin{array}{l}\text { Databases - Support } \\
\text { for Business }\end{array}$} & $\mathrm{I}$ & 14 & 0 & 14 & 2 & 4 & 6 & $42.6 \%$ \\
\hline & & II & 14 & 0 & 14 & 3 & 0 & 3 & $21.3 \%$ \\
\hline & & Total & 28 & 0 & 28 & 5 & 3 & 9 & $32.4 \%$ \\
\hline & \multirow{3}{*}{ E-business } & $\mathrm{I}$ & 10 & 0 & 10 & 4 & 1 & 5 & $50.0 \%$ \\
\hline & & II & 8 & 0 & 8 & 1 & 0 & 1 & $12.0 \%$ \\
\hline & & Total & 18 & 0 & 18 & 5 & 1 & 6 & $33.3 \%$ \\
\hline & \multirow{3}{*}{$\begin{array}{l}\text { Economic Financial } \\
\text { Criminology }\end{array}$} & $\mathrm{I}$ & 8 & 0 & 8 & 2 & 0 & 2 & $25.00 \%$ \\
\hline & & II & 7 & 3 & 10 & 0 & 2 & 2 & $20.00 \%$ \\
\hline & & Total & 15 & 3 & 18 & 2 & 2 & 4 & $22.22 \%$ \\
\hline & \multirow{3}{*}{$\begin{array}{l}\text { Information Systems } \\
\text { for the Management of } \\
\text { Economic Resources }\end{array}$} & I & 13 & 0 & 13 & 4 & 1 & 5 & $38.46 \%$ \\
\hline & & II & 10 & 0 & 10 & 0 & 1 & 1 & $10.00 \%$ \\
\hline & & Total & 23 & 0 & 23 & 4 & 2 & 6 & $26.09 \%$ \\
\hline & \multirow{3}{*}{ IT\&C Security } & $\mathrm{I}$ & 12 & 2 & 14 & 0 & 3 & 3 & $21.43 \%$ \\
\hline & & II & 10 & 0 & 10 & 0 & 3 & 3 & $30.00 \%$ \\
\hline & & Total & 22 & 2 & 24 & 0 & 6 & 6 & $25.00 \%$ \\
\hline & Management & $\mathrm{I}$ & 8 & 0 & 8 & 1 & 0 & 1 & $12.50 \%$ \\
\hline & Consulting and & II & 6 & 0 & 6 & 0 & 0 & 0 & $0.00 \%$ \\
\hline & Business Development & Total & 14 & 0 & 14 & 1 & 0 & 1 & $7.14 \%$ \\
\hline & \multirow{3}{*}{ Online Marketing } & $\mathrm{I}$ & 4 & 8 & 12 & 2 & 0 & 2 & $16.67 \%$ \\
\hline & & II & 5 & 6 & 11 & 1 & 0 & 1 & $9.09 \%$ \\
\hline & & Total & 9 & 14 & 23 & 3 & 0 & 3 & $13.04 \%$ \\
\hline & \multirow{3}{*}{ Statistics } & $\mathrm{I}$ & 8 & 0 & 8 & 0 & 1 & 1 & $12.50 \%$ \\
\hline & & II & 6 & 0 & 6 & 0 & 0 & 0 & $0.00 \%$ \\
\hline & & Total & 14 & 0 & 14 & 0 & 1 & 1 & $7.14 \%$ \\
\hline \multirow{6}{*}{ 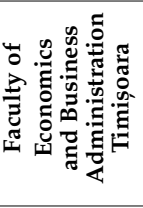 } & \multirow{3}{*}{$\begin{array}{l}\text { Business Information } \\
\text { Systems (FEEA, UVT) }\end{array}$} & I & 8 & 2 & 10 & 5 & 0 & 5 & $50.00 \%$ \\
\hline & & II & 7 & 3 & 10 & 2 & 2 & 4 & $40.00 \%$ \\
\hline & & Total & 15 & 5 & 20 & 7 & 2 & 9 & $45.00 \%$ \\
\hline & Financial-Banking & $\mathrm{I}$ & 8 & 5 & 13 & 1 & 0 & 1 & $7.69 \%$ \\
\hline & Information Systems & II & 8 & 2 & 10 & 1 & 1 & 2 & $20.00 \%$ \\
\hline & (FEEA, UVT) & Total & 16 & 7 & 23 & 2 & 1 & 3 & $13.04 \%$ \\
\hline & & $\mathrm{I}$ & 144 & 32 & 176 & 28 & 13 & 41 & $23.30 \%$ \\
\hline & rall results & II & 124 & 29 & 153 & 16 & 11 & 27 & $17.65 \%$ \\
\hline & & Total & 268 & 61 & 329 & 44 & 23 & 68 & $20.67 \%$ \\
\hline
\end{tabular}


Percent of CAMSS courses for master's degree courses (2017)

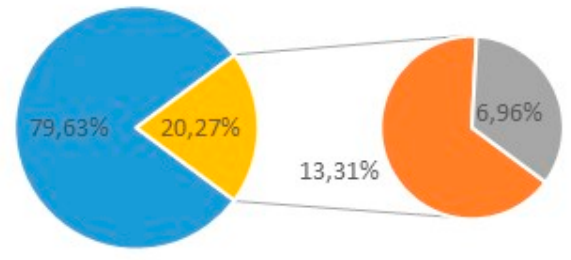

- Non-CAMSS

- Light CAMSS

- Core CAMSS

Figure 9. Percent of CAMSS courses in master's degree programs, detailed by light/core.

To understand the impact of the project at master's level, we performed a comparative analysis of the situation before project implementation and after it. Table 4 shows a comparison of CAMSS course percentages in master's degree curricula, before and after 2014.

For the 16 educational master's programs studied, 67 CAMSS topics were identified, of which 34 occurred in the academic year of 2013-2014, and 33 were introduced after that year. The changes we noticed in the case of master's programs showed a much higher impact, with an increase of $97 \%$. Practically, the implementation of the project has doubled the number of CAMSS courses delivered to students in the targeted educational programs.

In Figure 10, one can see a substantial increase in the number of CAMSS courses in master's programs that had little or no CAMSS content before implementation of the project. This is an encouraging result, as it shows that CAMSS subjects can be introduced into educational programs that did not previously teach computer science.

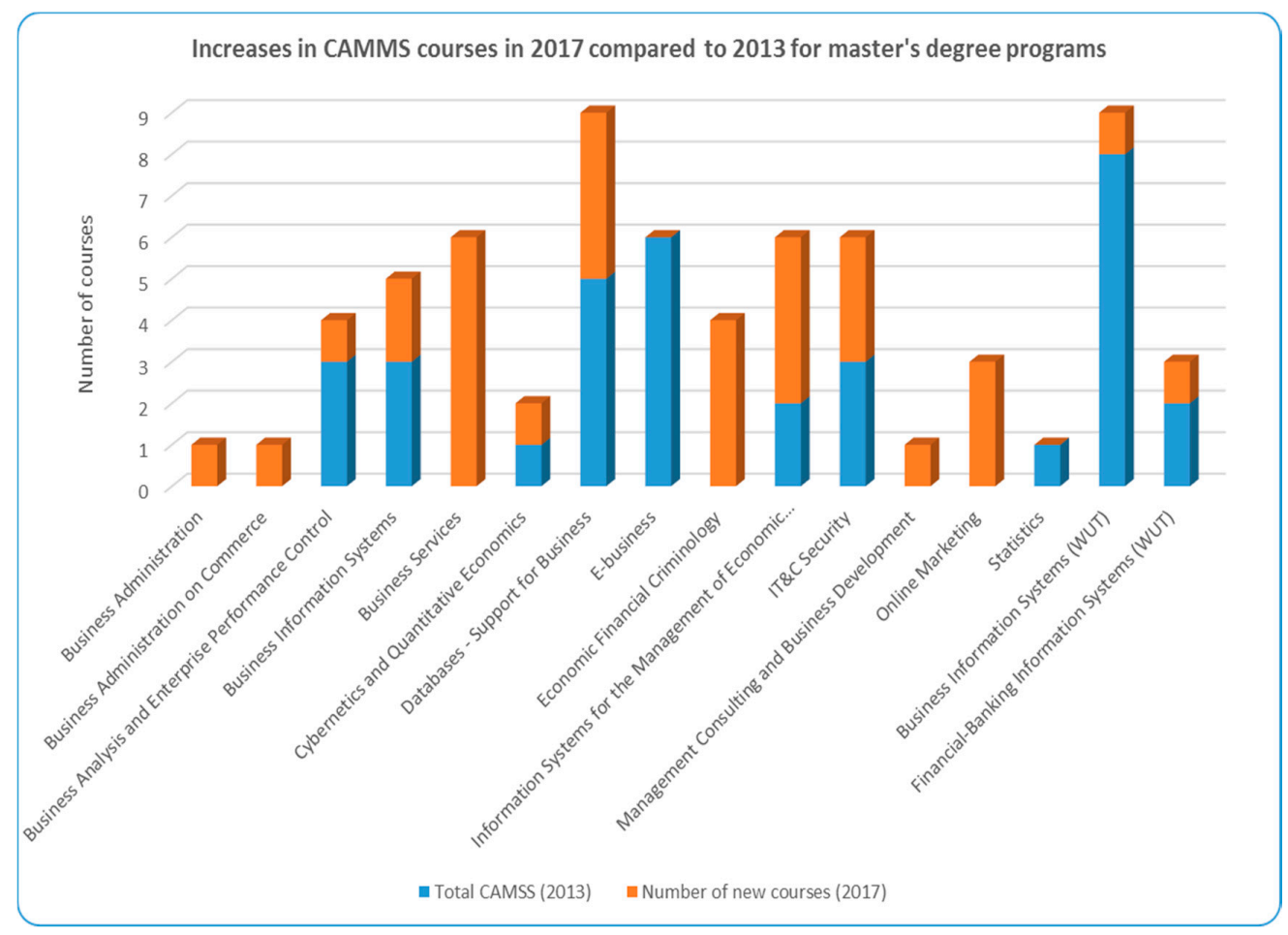

Figure 10. Increases in the number of CAMSS courses for master's degree programs in 2017 compared to 2013. 
Table 4. Comparison of CAMSS course percentages in master's degree curricula, before and after 2014.

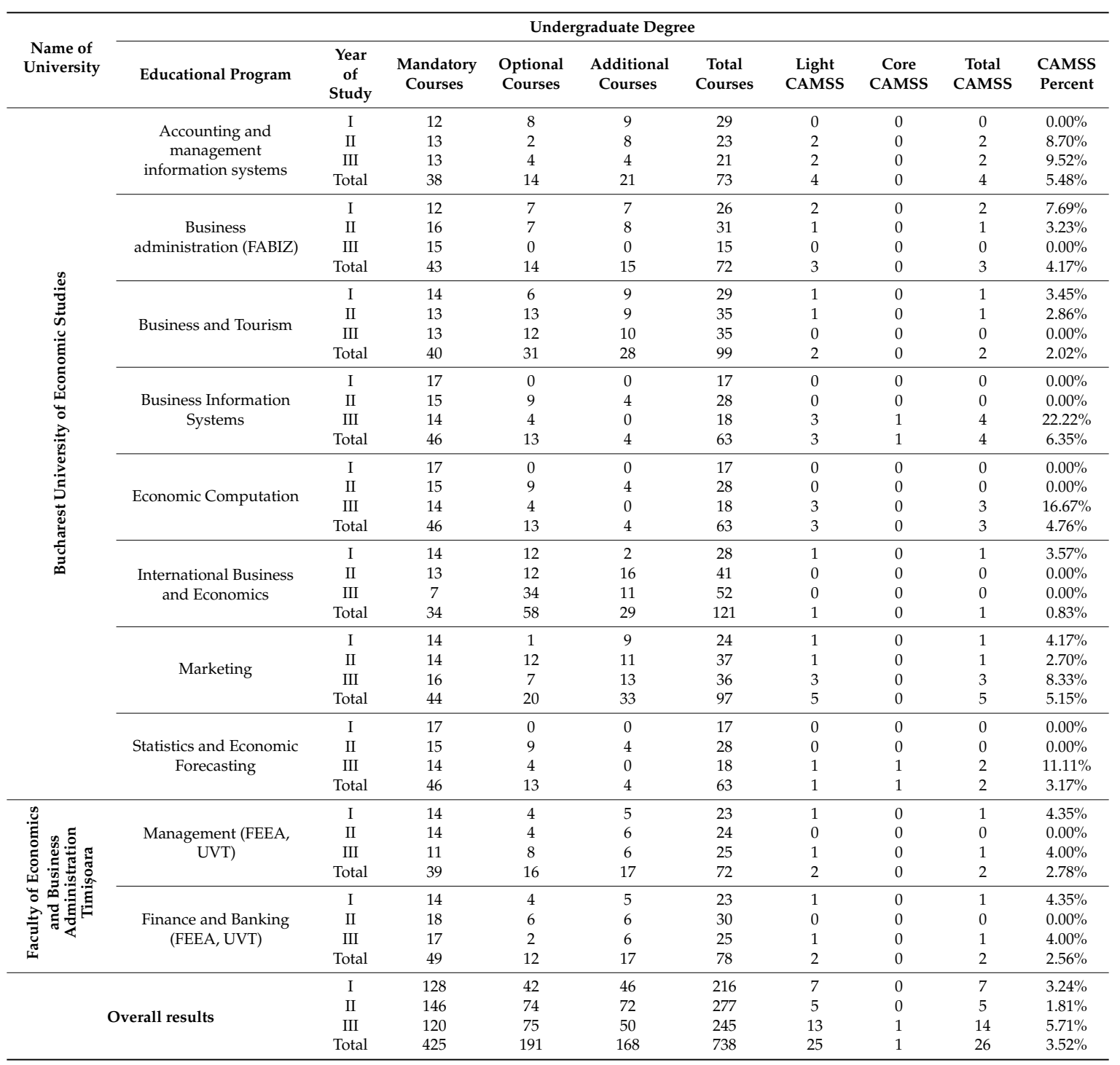

\subsection{Comparison of Curricula Changes between Undergraduate and Master Educational Programs}

To make a comparison between the number of changes in undergraduate and master's programs courses, we grouped master's programs by undergraduate specialization. We only considered courses related to cloud computing, big data, mobile programming, social networks and cybersecurity (CAMSS). When comparing the two sets of data, we can see several differences between curricula changes in undergraduate and master's degree educational programs (Figures 11 and 12). The average number of light CAMSS courses did not present significant differences between undergraduate and master's programs; however, there was a very significant increase in the number of core CAMSS courses included in the master's program compared to those of the undergraduate programs. 


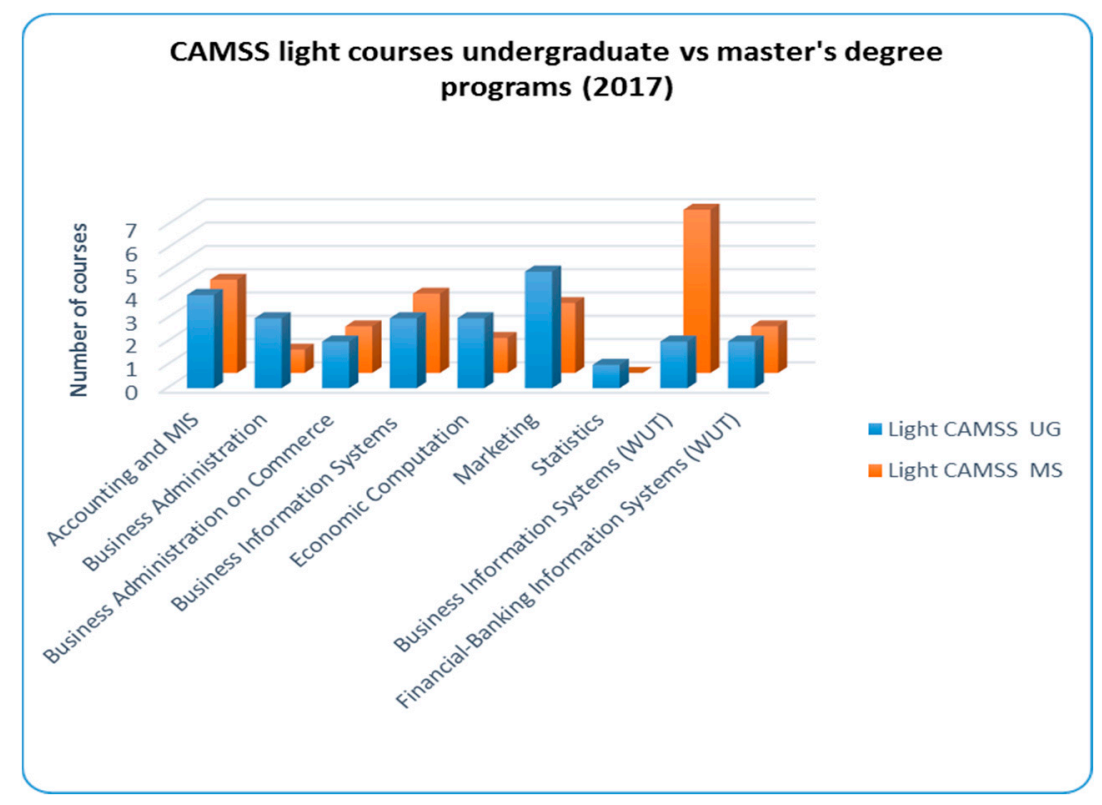

Figure 11. Comparison between the number of light CAMSS courses in undergraduate and master's degree programs.

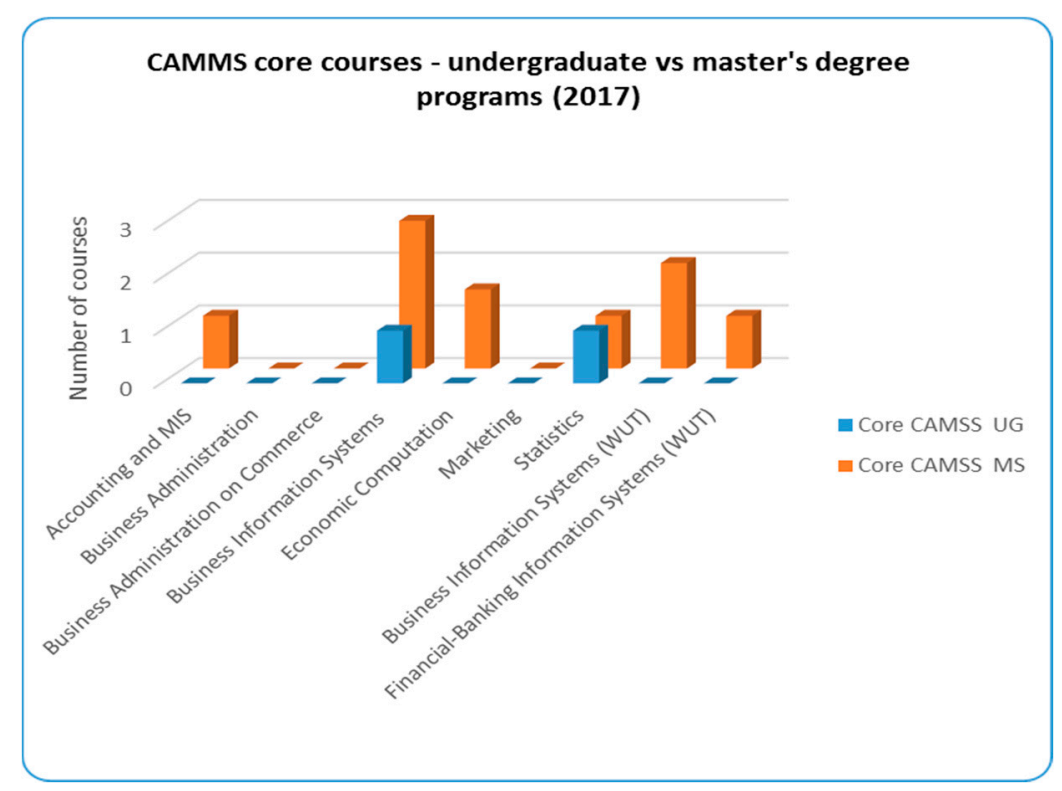

Figure 12. Comparison between the number of core CAMSS courses in undergraduate and master's degree programs.

A comparison between the percent of CAMSS courses in undergraduate degree versus master's degree educational programs reveal a much higher value for the second type of program: an average of $20.27 \%$ of courses versus only $3.73 \%$ for the undergraduates (Figures 4 and 9 , respectively). This difference appears to be caused by the following aspects:

(a) Undergraduate programs are usually oriented towards basic knowledge in the first two years of study, showing a lower number of technical courses.

(b) Courses based on new technologies can prove to be more difficult, even when they are intended to make things quicker and easier, and students may not be fully prepared. 


\subsection{Feedback from Students}

At the end of the course, all students were asked to fill in a feedback form and to answer detailed questions about the way they perceived the course. Figure 13 indicates the judgement of the students regarding the relevance of the CAMSS curricula for their education.

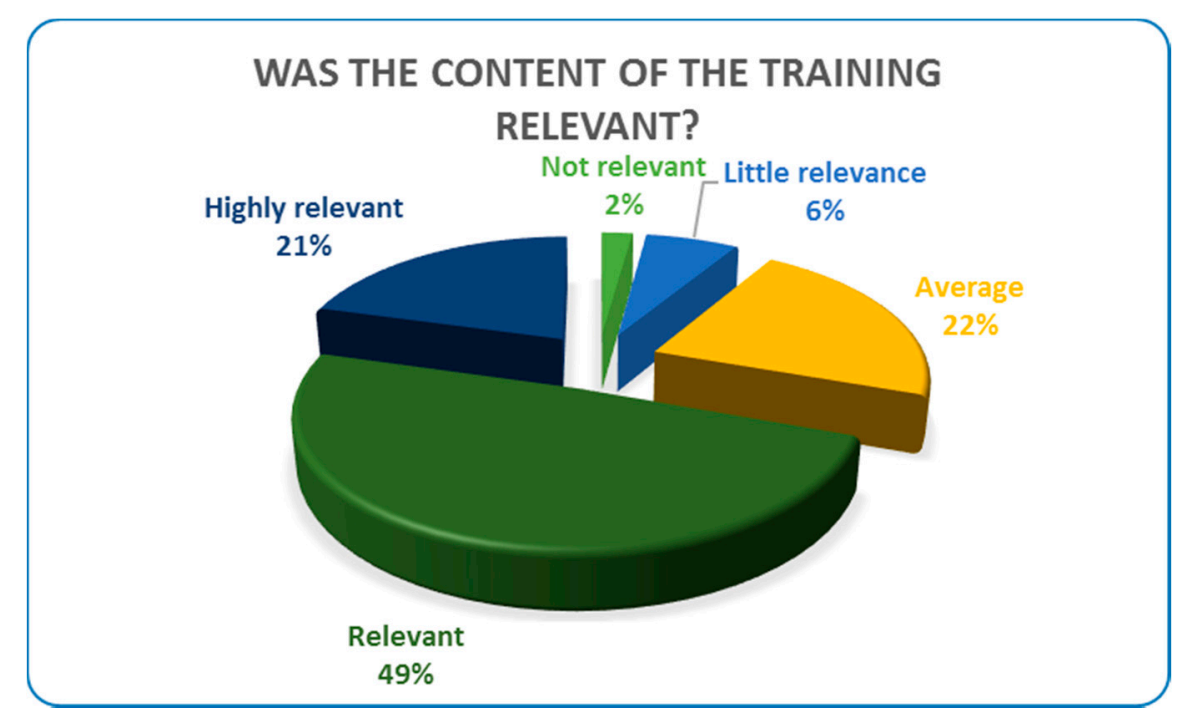

Figure 13. Relevance of the courses content according to student feedback forms.

It can be observed that most of the students considered the curricula to be relevant for their education. There were relatively few that considered the curricula to be irrelevant. This is an encouraging result as most of the students came from non-technical educational programs.

As presented in the introduction section, the need for digital jobs is growing fast. Ninety percent of organizations already have shortages in this area [28]. About $75 \%$ of educators and students feel that there is a gap between their ability to meet these needs and the demand of the IT workforce [28].

Education is the only factor that can decisively change this balance [29]. However, educators themselves have to undergo a process of reeducation, rethinking the content they offer in their courses and validating this content before restructuring and adjusting their academic offering [29]. On the other hand, the advantages of using technology in educational processes are indisputable: reducing the time in the training process, the possibility to adapt programs to the learners' needs, interdisciplinary promotion, and the possibility of simple adaptation to changes in different areas as well as essentially reducing the costs of continuous education [29].

The figures presented in the Results Section provide a quantifiable perspective on the dimension of the impact of the current project. The main value of the process is represented by the way in which it formalizes a succession of steps that are recommended to be followed in order to obtain a significant change of the learning offer in a short time.

\section{Conclusions}

First, we can state that the process did manage to improve the curricula of non-technical students by introducing modern technologies. The feedback of the students was positive and they showed interest in the new curricula. They did not reject the technical content, even though they were mostly studying business, finance, economics, statistics, marketing, and similar disciplines.

Modern technologies were adopted at a greater rate in master's programs than in undergraduate programs. The educational programs already teaching some older technologies as part of their curricula were, as expected, faster in adopting new curricular content. 
The impact of the process was monitored for a period of three years (2014-2017). For a better understating of the impact of the process in the medium and long run, it is necessary to continue monitoring this impact as part of future research by the authors.

Secondly, another important conclusion of the research is that advanced technologies seem to be receiving good feedback from non-technical students that consider them to be relevant for their education. This statement is supported by the results presented in Section 5.4. This appears to be an encouraging result for those attempting to insert technical curricula in the educational programs of non-technical students.

A third conclusion is that creating curricula is no longer a solo undertaking, as it has to be developed in a collaborative way, involving professors, social partners in education, and students. In contrast to the classical approach, where professors developed curricula on their own, in our approach professors were part of the project, as were the students.

Involving students in the process of curricular development via a pilot project proved to be a successful choice. Involving students in curricular development was a courageous decision that did not have precedent at the level of the two universities that were part of the project.

A fourth conclusion is that the proposed process fosters the coordination of different factors that are present at various levels in universities. By using our process, universities can obtain a good distribution of effects across graduate and undergraduate programs. The process does not consist of a set of procedures that need to be blindly implemented; it consists of guidelines for creating a community of professors, experts, and students that can work together to improve the curricula of academic educational programs.

Curriculum design is not a simple and rigid sequence of theoretical content and practical exercises uploaded to a platform. It is a collection of practices and objectives that have to be blended with theoretical content and practical exercises in order to offer students a real learning experience that can expand their knowledge.

When reviewing the literature on the need to adjust the academic curricula to the need for IT skills, there are many research papers discussing the importance of new technologies in the educational process, proposing the introduction of cloud-based topics in the curriculum of IT/technical educational programs [30-32] or analyzing the impact these changes have on education [33].

The present paper makes an integration of the key elements into one complete process: targeted IT skills, professors, course contents, professors, students, learning process, feedback, and validation of results over time, starting from setting up necessary curriculum updates, providing a discussion and feedback framework for process participants or other interested teachers, testing on a set of students to check if the level of complexity is appropriate, but also the involvement of decision-makers in universities in order to disseminate the knowledge and supporting materials developed.

Finally, we can state that our process offers the scientific community valuable results and describes a method for creating vibrant communities of curricular reformists. We do not limit ourselves to the accumulation of fact and theories; we have developed a method that other universities and/or companies could use to improve their curricular reform processes. This method was tested in two relevant environments. It is for this reason that we believe this article to constitute a step forward in developing modern academic educational programs that can sustain the employability of graduates.

Acknowledgments: As stated in the Introduction, this article is based on research conducted in a curricular reform project funded by the European Union under the grant number POSDRU/156/1.2/G/137499. The authors are entitled to publish the current results.

Author Contributions: R.B. conceived and designed the process and the experiments, A.-R. L analyzed the data and participated in the experiments, C.B. contributed with analysis tools and materials and T.M.G. gathered the statistical data and participated in the experiments.

Conflicts of Interest: The authors declare no conflicts of interest. The founding sponsors had no role in the design of the study; in the collection, analyses, or interpretation of data; in the writing of the manuscript, and in the decision to publish the results. 


\section{References}

1. Oesingmann, K. Youth Unemployment in Europe, CESifo DICE Report. Available online: http://www.cesifogroup.de/DocDL/dice-report-2017-1-oesingmann-march.pdf (accessed on 10 April 2017).

2. Tisch, A. The employability of older job-seekers: Evidence from Germany. J. Econ. Ageing 2015, 6, 102-112. [CrossRef]

3. Benjamin, D. Computer technology and probable job destructions in Japan: An evaluation. J. Jpn. Int. Econ. 2017, 43, 77-87.

4. Dascalu, M.I.; Bodea, C.-N.; Tesila, B.; Moldoveanu, A.; de Pablos, P.O. How social and semantic technologies can sustain employability through knowledge development and positive behavioral changes. Comput. Hum. Behav. 2017, 70, 507-517. [CrossRef]

5. World Economic Forum. The Future of Jobs, Employment, Skills and Workforce Strategy for the Fourth Industrial Revolution; World Economic Forum: Geneva, Switzerland, 2016.

6. Bologa, R.; Lupu, A.R. A Model for Predicting Future Demand for ICT Specialists in Romania. Econ. Comput. Econ. Cybern. Stud. Res. 2017, 51, 151-168.

7. Karre, H.; Hammera, M.; Kleindiensta, M.; Ramsauera, C. Transition towards an Industry 4.0 state of the LeanLab at Graz University of Technology. Procedia Manuf. 2017, 9, 206-213. [CrossRef]

8. Kozubal, J. Technical Universities for Civil Engineering Career in Republic of Poland. Procedia Eng. 2015, 117, 516-524. [CrossRef]

9. Toffler, A. The Third Wave; Bantam Books: New York, NY, USA, 1981; ISBN 9780553144314.

10. Schwab, K. The Fourth Industrial Revolution. 2015. Available online: https://www.foreignaffairs.com/ articles/2015-12-12/ fourth-industrial-revolution (accessed on 12 August 2017).

11. Jazdi, N. Cyber physical systems in the context of Industry 4.0. In Proceedings of the IEEE International Conference on Automation, Quality and Testing, Robotics, Cluj-Napoca, Romania, 22-24 May 2014; pp. 1-4.

12. Fuentes-Pila, J.; Garcia, J.; Murcho, D.; Baptista, F.; Silva, L.; Marques Da Silva, J.; Latini, A.; Campiotti, C.; Giagnacovo, C.; Perrin, L.; et al. Best Practices for Improving Energy Efficiency (in Agro-Industries), Technical Report TESLA IEE/12/758/S12.644752. 2015. Available online: https:/ / www.researchgate.net/publication/303767337_ Best_Practices_for_Improving_Energy_Efficiency_in_agro-industries (accessed on 2 October 2017).

13. Benešová, A.; Tupa, J. Requirements for Education and Qualification of People in Industry 4.0. Procedia Manuf. 2017, 11, 2195-2202. [CrossRef]

14. Wallner, T.; Wagner, G. Academic Education 4.0. In Proceedings of the International Conference on Education and New Developments, END 2016, Ljubljana, Slovenia, 12-14 June 2016; pp. 155-159.

15. Longo, F.; Nicoletti, L.; Padovano, A. Smart operators in industry 4.0: A human-centered approach to enhance operators' capabilities and competencies within the new smart factory context. Comput. Ind. Eng. 2017, 113, 144-159. [CrossRef]

16. Reis, M.; Gins, G. Industrial Process Monitoring in the Big Data/Industry 4.0 Era: From Detection, to Diagnosis, to Prognosis. Processes 2017, 5, 35. [CrossRef]

17. Pfeiffer, S. Robots, Industry 4.0 and humans, or why assembly work is more than routine work. Societies 2016, 6, 16. [CrossRef]

18. Hamiti, S.W.; Wydler, H. Supporting the integration of sustainability into higher education curricula-A case study from Switzerland. Sustainability 2014, 6, 3291-3300. [CrossRef]

19. Bertschy, F.; Künzli, C.; Lehmann, M. Teachers' competencies for the implementation of educational offers in the field of education for sustainable development. Sustainability 2013, 5, 5067-5080. [CrossRef]

20. Wijnker, M.; Van Kasteren, H.; Romijn, H. Fostering sustainable energy entrepreneurship among students: The Business Oriented Technological System Analysis (BOTSA) program at Eindhoven University of Technology. Sustainability 2015, 7, 8205-8222. [CrossRef]

21. Abele, E.; Chryssolouris, G.; Sihn, W.; Metternich, J.; El Maraghy, H.; Seliger, G.; Sivard, G.; El Maraghy, W.; Hummel, V.; Tisch, M.; et al. Learning factories for future oriented research and education. CIRP Ann. Manuf. Technol. 2017, 66, 803-8026. [CrossRef]

22. Prinz, C.; Morlock, F.; Freith, S.; Kreggenfeld, N.; Kreimeier, D.; Kuhlenkoter, B. Learning Factory Modules for Smart Factories in Industrie 4.0. Procedia CIRP 2016, 54, 113-118. [CrossRef]

23. Lüthje, C.; Prügl, R. Preparing business students for co-operation in multi-disciplinary new venture teams: Empirical insights from a business-planning course. Technovation 2006, 26, 211-219. [CrossRef] 
24. Giannakos, M.N.; Divitini, M.; Iversen, O.S. Entertainment, engagement, and education: Foundations and developments in digital and physical spaces to support learning through making. Entertain. Comput. 2017, 21, 77-81. [CrossRef]

25. Harel, I.; Papert, S. Constructionism; Ablex Publishing: New York, NY, USA, 1991; ISBN 978-0893917869.

26. Kafai, Y.B.; Resnik, M. Constructionism in Practice: Designing, Thinking, and Learning in a Digital World; Routledge: Abingdon, UK, 1996; ISBN 978-0805819854.

27. Bender, C. Is Your Infrastructure Prepared for Cloud, Analytics, Mobile, Security and Social? IBM Systems Magazine. March 2015. Available online: http:/ /ibmsystemsmag.com/power/businessstrategy/competitiveadvantage/ camss-ready / (accessed on 10 September 2017).

28. Frezzo, D. World Economic Forum: The Role of Technology in the Education of the Future. 2017. Available online: https: / /www.weforum.org/agenda/2017/05/science-of-learning/ (accessed on 1 October 2017).

29. Smeureanu, I.; Isaila, N. Information technology, support for innovation in education sciences. Procedia Soc. Behav. Sci. 2011, 15, 751-755. [CrossRef]

30. Chen, L.; Liu, Y.; Gallagher, M.; Pailthorpe, B.; Sadiq, S.; Shen, H.T.; Li, X. Introducing cloud computing topics in curricula. J. Inf. Syst. Educ. 2012, 23, 315.

31. Rabkin, A.S.; Reiss, C.; Katz, R.; Patterson, D. Experiences Teaching MapReduce in the Cloud. In Proceedings of the 43rd ACM Technical Symposium on Computer Science Education, Raleigh, NC, USA, 29 February 2012; pp. 601-606.

32. Changchit, C. Cloud Computing: Should it be Integrated into the Curriculum? Int. J. Inf. Commun. Technol. Educ. 2015, 11, 105-117. [CrossRef]

33. Shi, Y.; Yang, H.H.; Wu, Z. Trends of Cloud Computing in Education. In Proceedings of the International Conference on Hybrid Learning and Continuing Education, Shanghai, China, 8-10 August 2014; pp. 116-128.

(C) 2017 by the authors. Licensee MDPI, Basel, Switzerland. This article is an open access article distributed under the terms and conditions of the Creative Commons Attribution (CC BY) license (http:/ / creativecommons.org/licenses/by/4.0/). 